\title{
Liquid-Liquid Extraction of V(IV) from Sulphate Medium by Cyanex 301 Dissolved in Kerosene
}

\author{
Ranjit Kumar Biswas", Aneek Krishna Karmakar \\ Department of Applied Chemistry and Chemical Engineering, Rajshahi University, Rajshahi, Bangladesh \\ Email: "rkbiswas53@yahoo.com
}

Received November 21, 2012; revised December 20, 2012; accepted January 5, 2013

\begin{abstract}
The equilibrium of extraction of $\mathrm{V}(\mathrm{IV})$ in the $\mathrm{V}(\mathrm{IV})-\mathrm{SO}_{4}^{2-}\left(\mathrm{H}^{+}, \mathrm{Na}^{+}\right)$-Cyanex 301 (HA)-kerosene system has been studied. Significant extraction occurs above $\mathrm{pH} 1$ within $10 \mathrm{~min} .{ }^{\mathrm{C}} \mathrm{D}$ (extraction ratio at constant $\mathrm{pH}_{(\mathrm{eq})}$ and $[\mathrm{HA}]_{(\mathrm{o}, \mathrm{eq})}$ ) value is slightly decreased with increasing $[\mathrm{V}(\mathrm{IV})]_{\text {(ini) }}{ }^{\mathrm{C}} \mathrm{D}$ is found to be directly proportional to $\left[\mathrm{H}^{+}\right]^{-\mathrm{n}}(\mathrm{n} \leq 2),[\mathrm{HA}]^{2}$ and $\left(1+1.58\left[\mathrm{SO}_{4}^{2-}\right]\right)$. The process is endothermic $(\Delta \mathrm{H}=16 \mathrm{~kJ} / \mathrm{mol})$. Apparent $\mathrm{K}_{\mathrm{ex}}$ values at $303 \mathrm{~K}$ are $10^{-1.419}$ and $10^{-0.94}$ in 0.10 and $1.50 \mathrm{~mol} / \mathrm{L} \mathrm{SO}_{4}^{2-}$ medium, respectively. The loading capacity is calculated to be $7.87 \mathrm{~g} \mathrm{~V}(\mathrm{IV})$ per $100 \mathrm{~g}$ Cyanex 301. Kerosene appears as the best diluent. Stripping to the extents of $100 \%, 94 \%$ and $97.7 \%$ are possible in single stage by $1 \mathrm{~mol} / \mathrm{L} \mathrm{H}_{2} \mathrm{SO}_{4}, \mathrm{HCl}$ and $\mathrm{HNO}_{3}$, respectively. Separations of $\mathrm{V}$ (IV) from $\mathrm{Cu}$ (II) (at $\mathrm{pH} 0$ ), $\mathrm{Zn}$ (II) (at $\mathrm{pH} 0.5$ ) and $\mathrm{Fe}(\mathrm{III})$ (at $\mathrm{pH} 1.0$ ) by Cyanex 301 are possible.
\end{abstract}

Keywords: Extraction Equilibrium; Vanadium(IV); Cyanex 301; Kerosene; Sulphate

\section{Introduction}

Vanadium is widely used to prepare ferro-vanadium and the oxidative catalyst, $\mathrm{V}_{2} \mathrm{O}_{5}$. Almost $90 \%$ vanadium is used to prepare ferro-vanadium $(0.1 \%-0.3 \% \mathrm{~V})$ for automobile parts and high speed tools. Besides its use as oxidative catalyst, vanadium compounds are used in ink, dye, paint and varnish, insecticide, photographic chemicals, medicine and glass industries [1]. From carnotite $\left(\mathrm{K}_{2} \mathrm{U}_{2} \mathrm{~V}_{2} \mathrm{O}_{11} \cdot 3 \mathrm{H}_{2} \mathrm{O}\right)$, it is extracted with uranium by the DAPEX process. It is also extracted from vanadinite $\left(3 \mathrm{~Pb}_{3}\left(\mathrm{VO}_{4}\right)_{2} \cdot \mathrm{PbCl}_{2}\right)$. But in the present world, these ores together with patronite $\left(\mathrm{V}_{2} \mathrm{~S}_{3}\right)$ are rare on the earth's crust. So to meet up the demand, the processing of low grade ores and waste materials (tar sand, waste desulphurization catalyst, waste $\mathrm{SO}_{2}$-oxidation catalyst of contact process, slag, ash, rock etc.) are desirable. Prior roas- ting and leaching $[2,3]$ followed by solvent extraction is convenient for such purpose. It can build up concentra- tion by using low organic to aqueous phase ratio $(\mathrm{O} / \mathrm{A})$ in ex- traction and high $\mathrm{O} / \mathrm{A}$ in stripping.

Works published before 1976 on solvent extraction of V(IV) by various extractants have been summarized by Sekine and Hasegawa [4]. D2EHPA is a promising extractant for V(IV) and V(V) [5-11]. Saji and Reddy [12] have reported the extractions of $\mathrm{V}(\mathrm{IV})$ and $\mathrm{V}(\mathrm{V})$ by

"Corresponding author.
EHEHPA. In the field of solvent extraction, a delayed development is the use of organo-phosphinic compounds (Cyanex reagents) introduced by American Cyanamid and Cytec Canada Inc. Cyanex 302 and Cyanex 301 are mono-and di-sulphide analogues of Cyanex 272 (bis2,4,4-trimethylpentylphosphinic acid). The sulphur substitution decreases the $\mathrm{pK}_{\mathrm{a}}$ values $(6.4,5.6$ and 2.6 for Cyanex 272 [13], Cyanex 302 [14] and Cyanex 301 [15], respectively) permitting to work at lower $\mathrm{pH}$ [16]. Cyanex reagents differ from other commercial organophosphorous reagents (e.g. D2EHPA, DDPA, TBP, EHEHPA etc.) in that the former reagents contain P-C bonding, whereas the latter reagents contain P-O-C bonding. The presence of $\mathrm{P}-\mathrm{C}$ bonding in Cyanex reagents renders them to be less susceptible to hydrolysis and less soluble in water [17].

In recent past, the extraction behavior of V(IV) from $\mathrm{SO}_{4}^{2-}$ medium by Cyanex $272[18,19]$ and by Cyanex 302 [20] and of $\mathrm{V}(\mathrm{IV})$ and $\mathrm{V}(\mathrm{V})$ in presence of $\mathrm{Mo}(\mathrm{VI})$, $\mathrm{W}(\mathrm{VI}), \mathrm{U}(\mathrm{VI}), \mathrm{Ti}(\mathrm{IV}), \mathrm{Al}(\mathrm{III}), \mathrm{Cr}(\mathrm{III}), \mathrm{Fe}(\mathrm{III})$ from $\mathrm{Cl}^{-}$ medium by Cyanex 272 and HA [17] had been reported. There is no report on the equilibrium of the extraction of $\mathrm{V}(\mathrm{IV})$ from $\mathrm{SO}_{4}^{2-}$ medium by HA. The present paper reports the extraction characteristics of $\mathrm{V}(\mathrm{IV})$ from $\mathrm{SO}_{4}^{2-}$ medium by HA dissolved in kerosene in order to determine the effects of various parameters on extraction ratio and the value of $\mathrm{K}_{\mathrm{ex}}$; and also to propose mecha- 
nism. The loading of HA by V(IV) and the stripping ability of various mineral acids are also investigated. Finally, the possibilities of separation of V(IV) from some $3 d$-block cations in binary mixtures have been examined.

\section{Materials and Methods}

\subsection{Materials}

Cyanex 301 is a product of Cytec Canada Inc. and received as a gift. It contains $75 \%-83 \% \mathrm{R}_{2} \mathrm{PS}_{2} \mathrm{H}, 5 \%-8 \%$ $\mathrm{R}_{3} \mathrm{PS}, 3 \%-6 \% \mathrm{R}_{2} \mathrm{PSOH}$ and $2 \%$ unknown compound [21] and used without further purification since $\mathrm{R}_{3} \mathrm{PS}$ and $\mathrm{R}_{2} \mathrm{PSOH}$ have the extracting powers too. Kerosene purchased from the local market is distilled $\left(200^{\circ} \mathrm{C}-260^{\circ} \mathrm{C}\right)$ to collect the colorless aliphatic fraction. As-received $\mathrm{NH}_{4} \mathrm{VO}_{3}\left(99 \%\right.$, Riedel-deHaen) and $\mathrm{VOSO}_{4} \cdot \mathrm{xH}_{2} \mathrm{O}(99.9 \%$, Alfa Aesar-Johnson-Mathey), $\mathrm{H}_{2} \mathrm{O}_{2}(30 \%$ (w/v), MerckGermany) are used. Analytically pure diluents (besides kerosene) are the products of Riedel-deHaen and E. Merck-India.

\subsection{Analytical}

The aqueous $[\mathrm{V}(\mathrm{IV})]$ has been measured by the $\mathrm{HNO}_{3}$ oxidative- $\mathrm{H}_{2} \mathrm{O}_{2}$ method [22] at $450 \mathrm{~nm}$ using a UV-visible Spectrophotometer (UV-1650 PC, Shimadzu, Japan). For standard and test solution preparations, $\mathrm{NH}_{4} \mathrm{VO}_{3}$ and $\mathrm{VOSO}_{4} \cdot \mathrm{xH}_{2} \mathrm{O}$, respectively, are used. A Mettler Toledo $\mathrm{pH}$ meter (model MP 220) is used for $\mathrm{pH}$ measurement.

\subsection{Procedure for Extraction}

The procedure for extraction is given elsewhere $[20,23]$. Two phases are agitated at $\mathrm{O} / \mathrm{A}=1(\mathrm{O}=20 \mathrm{~mL})$ and 303 $\mathrm{K}$ (otherwise stated) for a predetermined time (15 $\mathrm{min})$. The phase separation is quick; and the aqueous phase after disengagement is analyzed for its $\mathrm{pH}_{(\mathrm{eq})}$ and $\mathrm{V}(\mathrm{IV})-$ content. Then " $\mathrm{D}$ " is calculated as usual [20,23].

\subsection{Procedure for Loading}

The loading procedure is given elsewhere [24]. An aliquot of $100 \mathrm{~mL} 0.20 \mathrm{~mol} / \mathrm{L}$ HA-kerosene solution has been used for V(IV)-loading from an aqueous solution containing $1.0 \mathrm{~g} / \mathrm{L} \mathrm{V}(\mathrm{IV})$ and $0.10 \mathrm{~mol} / \mathrm{L} \quad \mathrm{SO}_{4}^{2-}$ at $\mathrm{pH}_{\text {(ini) }}=$ 2.60. After each stage of contact, cumulative $[\mathrm{V}(\mathrm{IV})]_{(\mathrm{o}, \mathrm{eq})}$ is calculated to monitor the progress of stripping.

\subsection{Procedure for Stripping}

The stripping procedure is similar to the extraction procedure. The fully loaded organic solution obtained in the loading study is diluted to contain $200 \mathrm{mg} / \mathrm{L} \mathrm{V}$ (IV) and $0.10 \mathrm{~mol} / \mathrm{L} \mathrm{HA}$ in kerosene. Vanadium(IV) in this solution has been stripped by $(0.1,0.3$ or 1.0$) \mathrm{mol} / \mathrm{L}\left(\mathrm{H}_{2} \mathrm{SO}_{4}\right.$, $\mathrm{HCl}$ or $\mathrm{HNO}_{3}$ ) solution. A shaking time of $1 \mathrm{~h}$ is allowed arbitrarily. After equilibration and phase separation, the aqueous phase is analyzed for its [V(IV)] in order to calculate $\% \mathrm{~V}(\mathrm{IV})$ stripped by:

$$
\left([\mathrm{V}(\mathrm{IV})]_{(\mathrm{aq}, \mathrm{eq})} /[\mathrm{V}(\mathrm{IV})]_{(\mathrm{o}, \text { ini })}\right) \times 100
$$

\subsection{Treatment of Extraction Equilibrium Data}

$\mathrm{R}_{2} \mathrm{PS}_{2} \mathrm{H}$ is the principal constituent of Cyanex 301. This species is monomeric in non-polar diluents (owing to low electronegativity of sulphur) [21,25]. Consequently, Cyanex 301 has been abbreviated as HA. In aqueous solution, $\mathrm{VO}^{2+}$ can form complexes with co-existing $\mathrm{OH}^{-}$ and $\mathrm{HSO}_{4}^{-}$or $\mathrm{SO}_{4}^{2-}$. On considering the existence of $\left[\mathrm{VO}(\mathrm{OH})_{j} \mathrm{~L}_{k}\right]\left(\mathrm{L}\right.$ is $\mathrm{HSO}_{4}^{-}$or $\mathrm{SO}_{4}^{2-}$ and the charge of the complex is neglected for simplicity) in the aqueous phase and the monomeric charge-less extracted complex does not contain any $\mathrm{OH}^{-}$and $\mathrm{HSO}_{4}^{-}$or $\mathrm{SO}_{4}^{2-}$, the equilibrium for its extraction by $\mathrm{HA}$ can be represented as (" $\mathrm{x}$ ", " $2-j$ " and " $k$ " are experimental extractant, $\mathrm{pH}$ and co-existing ligand dependences, respectively):

$$
\begin{aligned}
{\left[\mathrm{VO}(\mathrm{OH})_{j} \mathrm{~L}_{k}\right]+\mathrm{xHA}_{(\mathrm{o})} \square } & {\left[\mathrm{VOA}_{2} \cdot(\mathrm{x}-2) \mathrm{HA}\right]_{(\mathrm{o})} } \\
+ & k \mathrm{~L}+(2-j) \mathrm{H}^{+}+j \mathrm{H}_{2} \mathrm{O}
\end{aligned}
$$

On defining " $D$ " as

$$
\left[\left[\mathrm{VOA}_{2} \cdot(\mathrm{x}-2) \mathrm{HA}\right]_{(\mathrm{o})}\right] /\left[\left[\mathrm{VO}(\mathrm{OH})_{j} \mathrm{~L}_{k}\right]\right]
$$

$\mathrm{K}_{\mathrm{ex}}$ of Equation (1) can be expressed as:

$$
\begin{aligned}
\log \mathrm{D}= & \log \mathrm{K}_{\mathrm{ex}}+(2-j) \mathrm{pH}_{(\mathrm{eq})} \\
& +\mathrm{x} \log [\mathrm{H} \mathrm{A}]_{(\mathrm{o}, \mathrm{eq})}-k \log [\mathrm{L}]_{(\mathrm{eq})}
\end{aligned}
$$

The Equation (2) represents the basic equation for solvated chelate formation by reaction of a metal ion with an acidic extractant. All concentration terms and $\mathrm{pH}$ in Equation (2) refer to the equilibrium values. Although it is difficult to collect $\mathrm{D}$-values experimentally at a constant set of $\mathrm{pH}_{(\mathrm{eq})}$, $[\mathrm{HA}]_{(\mathrm{o}, \mathrm{eq})}$ and $\left[\mathrm{SO}_{4}^{2-}\right]_{(\mathrm{eq})}$, it is possible to modify the experimental $\mathrm{D}$-values to ${ }^{C} \mathrm{D}$ values at a chosen set of constant $\mathrm{pH}_{(\mathrm{eq})},[\mathrm{HA}]_{(\mathrm{o}, \mathrm{eq})}$ and $\left[\mathrm{SO}_{4}^{2-}\right]_{(\mathrm{eq})}$. Since in almost all experiments, $0.10 \mathrm{~mol} / \mathrm{L} \mathrm{SO}_{4}^{2-} \quad(\sim 25$ times greater than [V(IV)]) has been used; it can be assumed that $\left[\mathrm{SO}_{4}^{2-}\right]_{(\mathrm{eq})}$ will not be significantly changed from $\left[\mathrm{SO}_{4}^{2-}\right]_{(\mathrm{ini})}$. Consequently, after determining the approximate $\mathrm{pH}$ and extractant dependences and rounding up these values, $\log { }^{\mathrm{C}} \mathrm{D}$ can be calculated by:

$$
\begin{aligned}
& \log { }^{\mathrm{C}} \mathrm{D} \\
= & \log \mathrm{D}+(2-j)\left(\text { constant } \mathrm{pH}_{(\mathrm{eq})} \text { chosen }-\mathrm{pH}_{(\mathrm{eq})} \text { exptl. }\right) \\
& +\mathrm{x}\left\{\log \left(\operatorname{constant}[\mathrm{HA}]_{(\mathrm{o}, \text { eq })} \text { chosen }\right)\right. \\
& \left.-\log \left([\mathrm{HA}]_{(\mathrm{o}, \text { ini })}-\mathrm{x}[\mathrm{V}(\mathrm{IV})]_{(\mathrm{o}, \text { eq })}\right)\right\}
\end{aligned}
$$


Moreover, $\left[\mathrm{H}_{2} \mathrm{~A}_{2}\right]_{(\mathrm{o}, \mathrm{eq})}$ is equal to

$$
\left[\mathrm{H}_{2} \mathrm{~A}_{2}\right]_{(\mathrm{o}, \mathrm{ini})}-\mathrm{x}[\mathrm{V}(\mathrm{IV})]_{(\mathrm{o}, \mathrm{eq})}
$$

Consequently, according to Equation (2), $\log { }^{\mathrm{C}} \mathrm{D}$ should be independent of [V(IV)] if the solutions behave ideally; while it should depend on $\mathrm{pH}_{(\mathrm{eq})}$, $[\mathrm{HA}]_{(\mathrm{eq})}$ or [L] at a constant set of other parameters. Moreover, as $\mathrm{K}_{\mathrm{ex}}$ is related to temperature by Van't Hoff equation, $\log { }^{C} \mathrm{D}$ will also depend on temperature.

\section{Results and Discussion}

\subsection{Extraction Equilibrium}

Some preliminary experiments indicate that $\mathrm{V}(\mathrm{IV})$ is extractable by $\mathrm{HA}$ at $\mathrm{pH} \sim 0.50$. When $0.20 \mathrm{~g} / \mathrm{L} \mathrm{V}(\mathrm{IV})$ containing $0.10 \mathrm{~mol} / \mathrm{L} \mathrm{SO}_{4}^{2-}$ at $\mathrm{pH}_{\text {(ini) }}$ of 2.30 is extracted by $0.10 \mathrm{~mol} / \mathrm{L} \mathrm{HA}$ in kerosene at $303 \mathrm{~K}$ and $\mathrm{O} / \mathrm{A}$ $=1$, then it is found that $[\mathrm{V}(\mathrm{IV})]_{(\mathrm{o})}$ is increased up to phase contact of $10 \mathrm{~min}$. It is therefore concluded that the equilibration time is $10 \mathrm{~min}$ (15 $\mathrm{min}$ is allowed in subsequent experiments).

Variation of "D" with [V(IV) $]_{(\mathrm{ini})}$ is found out at four different set of experimental parameters. It is found in all cases that $[\mathrm{V}(\mathrm{IV})]_{(\mathrm{o})}$ is increased, but ' $\mathrm{D}$ ' is decreased continuously with increasing $[\mathrm{V}(\mathrm{IV})]_{\text {(ini) }}$ in the aqueous phase. This is contrary to Equation (2) which is valid at constant $[\mathrm{HA}]_{(\mathrm{o}, \mathrm{eq})}$ and $\mathrm{pH}_{(\mathrm{eq})}$. The observed decreasing behavior might be due to the non-constancy of $[\mathrm{HA}]_{(\mathrm{o}, \mathrm{eq})}$ and $\mathrm{pH}_{(\mathrm{eq})}$ for various extents of $\mathrm{V}(\mathrm{IV})$ extraction. On calculating $\log { }^{\mathrm{C}} \mathrm{D}$ (by Equation (3) on considering " 2 $j "=1.50$ at constant $\mathrm{pH}_{(\mathrm{eq})}$ of 1.40 or 1.67 at constant $\mathrm{pH}_{\text {(eq) }}$ of 1.80 and $\mathrm{x}=2.00$ for all systems), $\log { }^{\mathrm{C}} \mathrm{D}$ vs. $\log \left([\mathrm{V}(\mathrm{IV})]_{\text {(ini) }}, \mathrm{mol} / \mathrm{L}\right)$ plots are drawn in Figure 1. Plots indicate the independency of ${ }^{\mathrm{C}} \mathrm{D}$ on [V(IV)] at least up to $300 \mathrm{mg} / \mathrm{L}$. Systems with higher [V(IV] behave nonideally.

At a constant $[\mathrm{HA}]_{(0, \text { eq })}$, the plot of $\log \mathrm{D} \mathrm{vs} \mathrm{pH}_{(\mathrm{eq})}$ should be a straight line with slope equaling to " $2-j$ " (cf. Equation (2)). For low $\left[\mathrm{SO}_{4}^{2-}\right.$ ] of $0.10 \mathrm{~mol} / \mathrm{L}$, Figure 2 represents $\log { }^{\mathrm{C}} \mathrm{D}$ vs $\mathrm{pH}_{(\mathrm{eq})}$ plots at constant $[\mathrm{HA}]_{(\mathrm{o}, \mathrm{eq})}$ of 0.20 and $0.30 \mathrm{~mol} / \mathrm{L}$. In both cases, straight lines are not obtained. Three or four points at $\mathrm{lpHr}$ produce straight lines of slope 2. At $h p H r$, the slope is decreased gradually and at $\mathrm{pH} 2.15$, it becomes 1.6. It is concluded that single type of extractable species is formed from two different types of aqueous $\mathrm{V}(\mathrm{IV})$ species, viz. $\mathrm{VO}^{2+}$ and $\mathrm{VO}(\mathrm{OH})^{+}$. In the first case, two $\mathrm{H}^{+}$are liberated; whereas, in the second case, one $\mathrm{H}^{+}$is liberated, per $\mathrm{V}(\mathrm{IV})$ being extracted into the organic phase. As an evidence to this statement, the formation of same extractable species from $\mathrm{VO}^{2+}, \mathrm{VO}(\mathrm{OH})^{+}$and $\mathrm{VO}(\mathrm{OH})_{2}$ by D2EHPA may be cited [5]. The effect of $\mathrm{pH}$ on extraction at hor of $\left[\mathrm{SO}_{4}^{2-}\right]$ $(1.50 \mathrm{~mol} / \mathrm{L})$ has also been investigated (cf. Figure 2). A

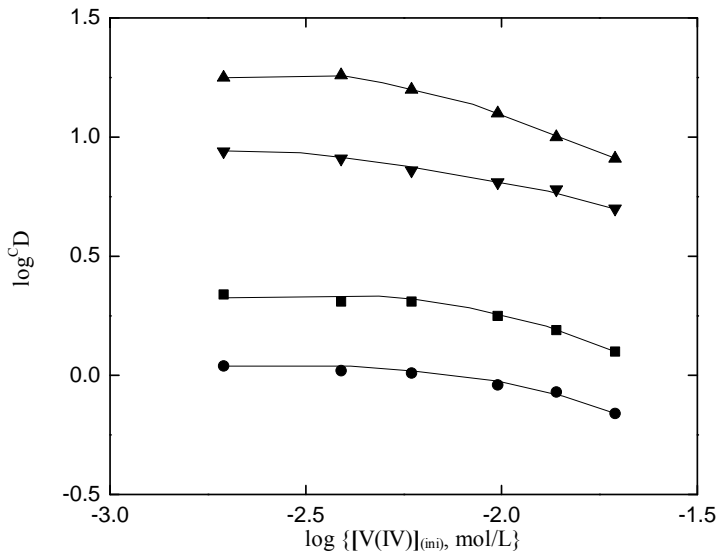

Figure 1. Effect of $[\mathrm{V}(\mathrm{IV})]$ on its extraction. Temp. $=303 \mathrm{~K}$, $\left[\mathrm{SO}_{4}^{2-}\right]=0.10 \mathrm{~mol} / \mathrm{L}$, Equilibration time $=15 \mathrm{~min}, \mathrm{O} / \mathrm{A}=1$ $(\mathrm{O}=20 \mathrm{~mL}) .(\square), \mathrm{pH}_{(\mathrm{ini})}=1.52$, constant $\mathrm{pH}_{(\mathrm{eq})}$ chosen $=1.4$, $[\mathrm{HA}]_{(o, \text { ini) }}=0.30 \mathrm{~mol} / \mathrm{L}=[\mathrm{HA}]_{(0, \mathrm{eq})} ;(\Theta), \mathrm{pH}_{(\mathrm{ini})}=1.52$, , constant $\mathrm{pH}_{(\mathrm{eq})} \operatorname{chosen}=1.42,[\mathrm{HA}]_{(o, \text { ini })}=0.20 \mathrm{~mol} / \mathrm{L}=[\mathrm{HA}]_{(\mathrm{o}, \mathrm{eq})}$; $(\Delta), \mathbf{p H}_{(\mathrm{ini})}=1.90$, constant $\mathbf{p H}_{(\mathrm{eq})}$ chosen $=1.78,[\mathrm{HA}]_{(0, \text { ini) }}=$ $0.30 \mathrm{~mol} / \mathrm{L}=[\mathrm{HA}]_{(0, \mathrm{eq})}$; and $(\nabla), \mathrm{pH}_{(\mathrm{ini})}=1.90$, constant $\mathrm{pH}_{(\mathrm{eq})} \operatorname{chosen}=1.78[\mathrm{HA}]_{(0, \text { ini })}=0.20 \mathrm{~mol} / \mathrm{L}=[\mathrm{HA}]_{(\mathrm{o}, \mathrm{eq})}$.

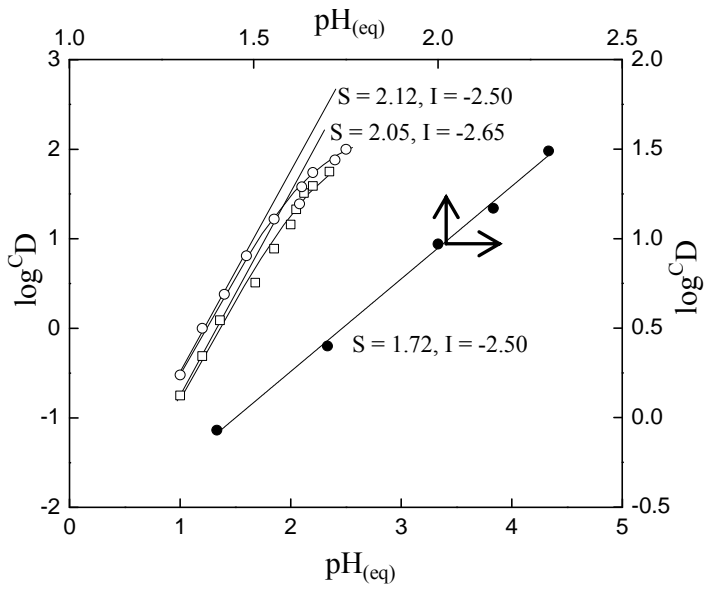

Figure 2. Effect of $\mathbf{p H}_{(\mathrm{eq})}$ on extraction. $[\mathrm{V}(\mathrm{IV})]_{(\mathrm{ini})}=\mathbf{2 0 0}$ $\mathrm{mg} / \mathrm{L}$. (O), $[\mathrm{HA}]_{(0, \text { ini })}=0.30 \mathrm{~mol} / \mathrm{L}=[\mathrm{HA}]_{(0, \mathrm{eq})} ;(\square),[\mathrm{HA}]_{(0, \text { ini })}$ $=0.20 \mathrm{~mol} / \mathrm{L}=[\mathrm{HA}]_{(0, \mathrm{eq})} ;(\Theta),\left[\mathrm{SO}_{4}^{2-}\right]=1.50 \mathrm{~mol} / \mathrm{L}$, $[\mathrm{HA}]_{(0, \text {,ini) }}=0.15 \mathrm{~mol} / \mathrm{L}=[\mathrm{HA}]_{(0, \mathrm{eq})}$. Other parameters are as in Figure 1.

straight line having slope of 1.72 is obtained. It is therefore concluded that the $\mathrm{pH}$ dependency in the present system depends on $\left[\mathrm{SO}_{4}^{2-}\right]$. As $\left[\mathrm{SO}_{4}^{2-}\right]$ is increased, $\mathrm{pH}$ dependency is decreased.

According to Equation (2), the plot of $\log { }^{\mathrm{C}} \mathrm{D}$ vs. $\log$ $[\mathrm{HA}]_{(\mathrm{o}, \text { eq) }}$ at a constant $\mathrm{pH}_{(\mathrm{eq})}$ should be a straight line with slope giving moles of $\mathrm{HA}(\mathrm{x})$ associated with $1 \mathrm{~mol}$ of V(IV) in extracted species. The $\log \mathrm{D}$ vs $\log [\mathrm{HA}]_{(\mathrm{o}, \text { ini) }}$ plots (as there will be a very little variation between $\mathrm{pH}_{(\mathrm{ini})}$ and $\mathrm{pH}_{(\mathrm{eq})}$ and between $[\mathrm{HA}]_{(\mathrm{o}, \text { ini) }}$ and $\left.[\mathrm{HA}]_{(\mathrm{o}, \mathrm{eq})}\right)$ are shown in Figure 3. Straight lines having slope of 2 are indeed obtained at both lcr and hor of $\mathrm{SO}_{4}^{2-}$. It is 


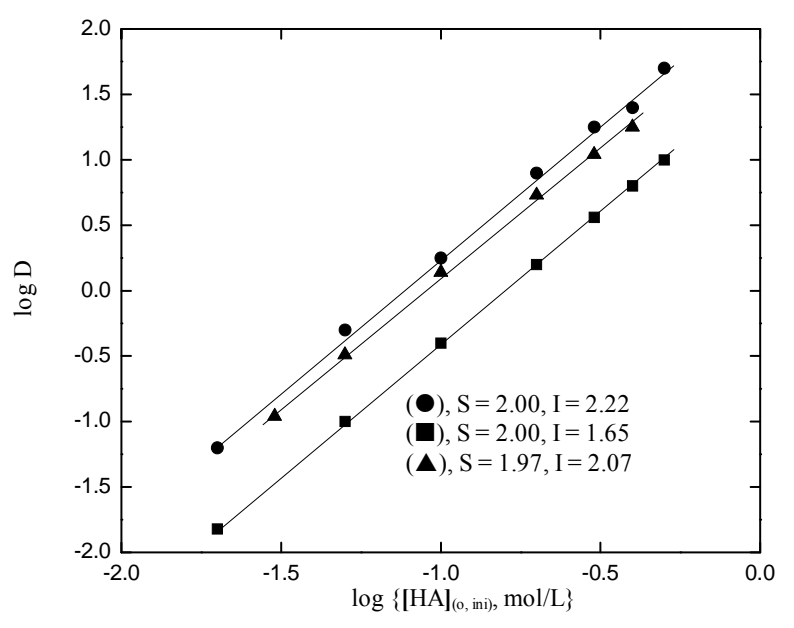

Figure 3. Effect of $[\mathrm{HA}]_{(0, \text { eq }}$ on extraction. $(\bigcirc), \mathrm{pH}_{(\mathrm{ini})}=\mathbf{2 . 0 0}$; $(\square), \mathrm{pH}_{\text {(ini) }}=1.50 ;(\Delta), \mathrm{pH}_{\text {(ini) }}=1.40,\left[\mathrm{SO}_{4}^{2-}\right]=1.50 \mathrm{~mol} / \mathrm{L}$. Other parameters are as in Figure 1.

therefore concluded that the HA-dependency is always 2 irrespective of $\left[\mathrm{SO}_{4}^{2-}\right]$, though the $\mathrm{pH}$-dependency is dependent of $\left[\mathrm{SO}_{4}^{2-}\right]$.

The $\log { }^{\mathrm{C}} \mathrm{D}$ vs $\log \left(\left[\mathrm{SO}_{4}^{2-}\right], \mathrm{mol} / \mathrm{L}\right)$ plot is displayed in Figure 4. Experimental points fall on a curve. In lcr of $\mathrm{SO}_{4}^{2-},{ }^{\mathrm{C}} \mathrm{D}$ is seldom changed; whilst in the hcr, it is considerably increased with increasing $\left[\mathrm{SO}_{4}^{2-}\right]$. The curve in the figure is theoretical and represented by:

$$
\log ^{\mathrm{C}} \mathrm{D}=0.95+\log \left(1+1.58\left[\mathrm{SO}_{4}^{2-}\right]\right)
$$

which is obtained to fit experimental points as described in the caption of Figure 4. It is seen that $\left[\mathrm{SO}_{4}^{2-}\right]$ has little effect on extraction when its concentration is kept $\sim 0.10 \mathrm{~mol} / \mathrm{L}$; but at her of $\left[\mathrm{SO}_{4}^{2-}\right], \log { }^{\mathrm{C}} \mathrm{D}$ is almost directly proportional to $\log \left[\mathrm{SO}_{4}^{2-}\right]$.

The Van't Hoff plots are shown in Figure 5. It is found that ${ }^{C} \mathrm{D}$ is increased with increasing temperature and the straight line relationship holds. Slopes of the lines are $-870(\Delta \mathrm{H}=16.70 \mathrm{~kJ} / \mathrm{mol})$ and $-830(\Delta \mathrm{H}=$ $15.95 \mathrm{~kJ} / \mathrm{mol}$ ) for $\mathrm{pH}=1.35$ and 1.25 systems, respecttively. Therefore, the process is endothermic with low $\Delta \mathrm{H}$ value of $\sim 16 \mathrm{~kJ} / \mathrm{mol}$.

It is evident from these studies that the value of " $\mathrm{x}$ " is 2 irrespective of the experimental parameter but the value of " $k$ " is 0 at low $\left[\mathrm{SO}_{4}^{2-}\right]$ and -1 at high $\left[\mathrm{SO}_{4}^{2-}\right]$. The value of " $2-j$ " is 2 in low $\mathrm{pH}_{(\mathrm{eq})}$ and $<2$ in high $\mathrm{pH}_{(\mathrm{eq})}$. At $l c r$ of $\mathrm{SO}_{4}^{2-}$ and at $l p H_{(e q)} r, " 2-j "=2 \mathrm{im}-$ plies that " $j "=0$; but at $h p H_{(e q)} r, " 2-j "<2$ (but $>1$ ) implies that $1<j<2$. On the other hand, at her of $\mathrm{SO}_{4}{ }^{2-}$ and at both $l p H_{(e q)} r$ and $h p H_{(e q)} r$, " $2-j "<2$ implies $j>0$.

\subsection{Evaluation of Extraction Equilibrium Constant}

The foregoing results give the equation for $\log ^{\mathrm{C}} \mathrm{D}$ at 303

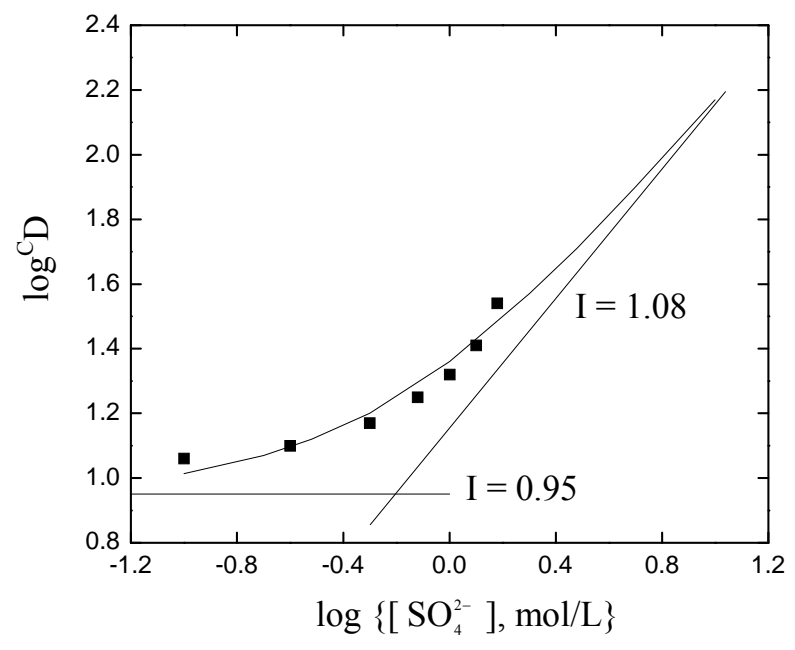

Figure 4. Effect of $\left[\mathrm{SO}_{4}^{2-}\right]$ on extraction. $\mathrm{pH}_{(\text {ini) }}=\mathbf{2 . 0 0}=$ $\mathrm{pH}_{(\mathrm{eq})},[\mathrm{HA}]_{(0, \text { ini) }}=0.225 \mathrm{~mol} / \mathrm{L}=[\mathrm{HA}]_{(0, \mathrm{eq})}$. Other parameters are as in Figure 1. Experimental points fall on a curve represented by: $\log ^{\mathrm{C}} \mathrm{D}=$ constant $+\log \left(1+\mathrm{K}_{\mathrm{SO}_{4}}\left[\mathrm{SO}_{4}^{2-}\right]\right)$. The curve possesses two asymptotes: at $\mathrm{lcr}$ of $\mathrm{SO}_{4}^{2-}: \log ^{\mathrm{C}} \mathrm{D}$ = constant (represented by horizontal line) and at hor of $\mathrm{SO}_{4}^{2-}: \log { }^{\mathrm{C}} \mathrm{D}=$ constant $+\log \mathrm{K}_{\mathrm{so}_{4}}+\log \left[\mathrm{SO}_{4}^{2-}\right]$ (represented by inclined line). At the point of intersection of two asymptotes: $\log \mathrm{K}_{\mathrm{SO}_{4}}+\log \left[\mathrm{SO}_{4}^{2-}\right]=0$; or, $\log \mathrm{K}_{\mathrm{SO}_{4}}=$ $-\log \left[\mathrm{SO}_{4}^{2-}\right]=-(-0.20)=0.20 ;$ or, $\log \mathrm{K}_{\mathrm{SO}_{4}}=1.58$. Intercept of asymptote at hor is 1.08 and that at lcr is 0.95 .

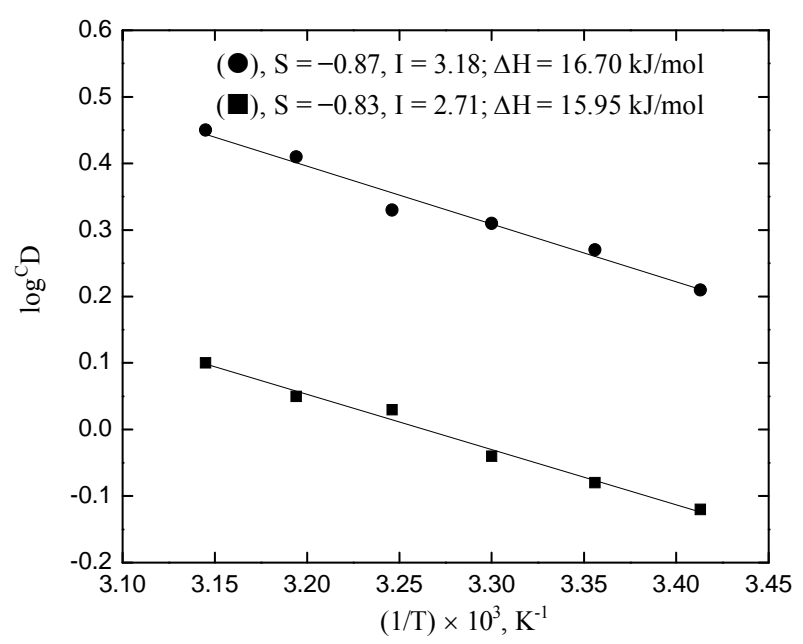

Figure 5. Effect of temperature on extraction. ( $\bigcirc), \mathrm{pH}_{(\mathrm{ini})}=$ $1.35,[\mathrm{HA}]_{(0, \text { ini) }}=0.30 \mathrm{~mol} / \mathrm{L}=[\mathrm{HA}]_{(0, \text { ini })} ;(\mathbf{\square}), \mathrm{pH}_{(\mathrm{ini})}=1.25$, $[\mathrm{HA}]_{(\text {ini) }}=0.20 \mathrm{~mol} / \mathrm{L}=[\mathrm{HA}]_{(o, \text { ini) }}$. Other parameters are as in Figure 1.

$\mathrm{K}$ in lcr of sulphate as:

$$
\begin{aligned}
\log ^{\mathrm{C}} \mathrm{D}= & \log \mathrm{K}_{\mathrm{ex}}+2 \mathrm{pH}_{(\mathrm{eq})}+2 \log [\mathrm{HA}]_{(\mathrm{o}, \text { eq })} \\
& +\log \left(1+1.58\left[\mathrm{SO}_{4}^{2-}\right]\right)
\end{aligned}
$$


Based on Equation (5), value of $\log \mathrm{K}_{\mathrm{ex}}$ has been evaluated from intercepts of the straight lines or asymptotic lines in Figures (2)-(4) and tabulated (Table 1). The average $\log \mathrm{K}_{\mathrm{ex}}$ is -1.419 at lcr of $\mathrm{SO}_{4}^{2-}$ with stand. dev. of 0.105 . Besides, $\log { }^{\mathrm{C}} \mathrm{D}$ at $303 \mathrm{~K}$ in her of $\mathrm{SO}_{4}^{2-}$ can be put as:

$$
\begin{aligned}
\log { }^{\mathrm{C}} \mathrm{D}= & \log \mathrm{K}_{\mathrm{ex}}+1.72 \mathrm{pH}_{(\mathrm{eq})}+2 \log [\mathrm{HA}]_{(\mathrm{o}, \text { eq })} \\
& +\log 1.58+\log \left[\mathrm{SO}_{4}^{2-}\right]
\end{aligned}
$$

On using Equation (6), $\log \mathrm{K}_{\mathrm{ex}}$ is evaluated as -0.94 with stand. dev. of 0.026 .

\subsection{Extraction Mechanism}

The empirical equation for $\mathrm{K}_{\mathrm{ex}}$ at $303 \mathrm{~K}$ is:

$$
\begin{aligned}
\mathrm{K}_{\mathrm{ex}} & =10^{-1.42} \\
& =\frac{[\mathrm{V}(\mathrm{IV})]_{(\mathrm{o})}\left[\mathrm{H}^{+}\right]^{\leq 2}\left(1+1.58\left[\mathrm{SO}_{4}^{2-}\right]\right)^{-1}}{[\mathrm{~V}(\mathrm{IV})][\mathrm{HA}]_{(\mathrm{o})}^{2}}
\end{aligned}
$$

The 1 st and 2nd ionization constants of $\mathrm{H}_{2} \mathrm{SO}_{4}$ are $10^{3}$ [26] and $10^{-2}$ [27], respectively. These values suggest that $\mathrm{SO}_{4}^{2-}$ will be more available than $\mathrm{HSO}_{4}^{-}$in the working $\mathrm{pH}$ region. So, $\mathrm{L}$ in Equation (1) represents $\mathrm{SO}_{4}^{2-}$. As the values of " $\mathrm{x}$ ", " $k$ ", " $l$ " and " $(2-j)$ " are known at different experimental conditions, Equation (1) will provide extraction mechanisms. Although in Equation (1), "L" is presented as a product (liberated during complex formation); experimental results indicate that it is associated with V(IV) during complex formation. As " $\mathrm{x}$ " is always 2 , non-solvated chelate $\left(\mathrm{VOA}_{2}\right)$ is formed at lcr of $\mathrm{SO}_{4}^{2-}$, whereas, solvated complex

$\left(\mathrm{VOSO}_{4} \cdot 2 \mathrm{HA}\right)$ is formed at her of $\mathrm{SO}_{4}^{2-}$. Typical equilibria are suggested as:

1) in lcr of $\mathrm{SO}_{4}^{2-}$ and $\mathrm{lpHr}$ :

$$
\mathrm{VO}^{2+}+2 \mathrm{HA}_{(\mathrm{o})} \square\left[\mathrm{VOA}_{2}\right]_{(\mathrm{o})}+2 \mathrm{H}^{+}
$$

2) in lcr of $\mathrm{SO}_{4}^{2-}$ and $h p H r$ (limiting):

$$
\mathrm{VO} \cdot \mathrm{OH}^{+}+2 \mathrm{HA}_{(\mathrm{o})} \square\left[\mathrm{VOA}_{2}\right]_{(\mathrm{o})}+\mathrm{H}_{2} \mathrm{O}+\mathrm{H}^{+}
$$

3) in her of $\mathrm{SO}_{4}^{2-}$ (limiting):

$$
\mathrm{VO}^{2+}+\mathrm{SO}_{4}^{2-}+2 \mathrm{HA}_{(\mathrm{o})} \square\left[\mathrm{VO} \cdot \mathrm{SO}_{4} \cdot 2 \mathrm{HA}\right]_{(\mathrm{o})}
$$

An alternative option of the formation of $\left[\mathrm{VO} \cdot \mathrm{SO}_{4} \cdot 2 \mathrm{HA}\right]_{(\mathrm{o})}$ may be the formation of $\left[\mathrm{VO}\left(\mathrm{HSO}_{4}\right)(\mathrm{A}) \cdot \mathrm{HA}\right]_{(\mathrm{o})}$ with the simultaneous liberation of a proton. These are only presumptions from the experimental results and not proven by other means.

\subsection{Effect of Diluent}

In order to determine the effect of diluent on V(IV)-distribution, D-values have been measured when the same aqueous phase has been extracted separately by 0.10 mol/L HA in different diluents keeping all other parametric conditions $\left([\mathrm{V}(\mathrm{IV})]=200 \mathrm{mg} / \mathrm{L}, \mathrm{pH}_{(\mathrm{ini})}=2.00\right.$ and $\left.\left[\mathrm{SO}_{4}^{2-}\right]=0.01 \mathrm{~mol} / \mathrm{L}\right)$ identical. It is observed that the extraction ratio increases in the following order with the variation of diluent: $\mathrm{CHCl}_{3}(\varepsilon=4.807 ; \mathrm{D}=0.42)<$ $1,2-\mathrm{C}_{2} \mathrm{H}_{4} \mathrm{Cl}_{2}(\varepsilon=10.42 ; \mathrm{D}=0.54)<\mathrm{C}_{6} \mathrm{H}_{4}-\left(\mathrm{CH}_{3}\right)_{2}(\varepsilon=$ $2.26 ; \mathrm{D}=0.68)<$ cyclo- $\mathrm{C}_{6} \mathrm{H}_{12}(\varepsilon=2.02 ; \mathrm{D}=1.31)=$ $\mathrm{C}_{6} \mathrm{H}_{5} \mathrm{Cl}(\varepsilon=5.69 ; \mathrm{D}=1.31)<\mathrm{C}_{6} \mathrm{H}_{5}-\mathrm{CH}_{3}(\varepsilon=2.385 ; \mathrm{D}=$ $1.64)<\mathrm{n}^{-\mathrm{C}_{7} \mathrm{H}_{16}}(\varepsilon=1.921 ; \mathrm{D}=2.08)=\mathrm{C}_{6} \mathrm{H}_{6}(\varepsilon=2.274$; $\mathrm{D}=2.08)<\mathrm{CCl}_{4}(\varepsilon=2.228 ; \mathrm{D}=2.34)<$ petroleum ben$\operatorname{zin}(\mathrm{D}=3.62)<$ kerosene $(\varepsilon=2.00 ; \mathrm{D}=3.93)$. The study helps draw the conclusion that kerosene is a very good diluent followed by petroleum benzin and $\mathrm{CCl}_{4}$ for the extraction of $\mathrm{V}(\mathrm{IV})$ by Cyanex 301. $\mathrm{CHCl}_{3}, 1,2-\mathrm{C}_{2} \mathrm{H}_{4} \mathrm{Cl}_{2}$ and $\mathrm{C}_{6} \mathrm{H}_{4}\left(\mathrm{CH}_{3}\right)_{2}$ are not recommended. $79.72 \% \mathrm{~V}(\mathrm{IV})$ extraction in kerosene phase is decreased to only $29.70 \%$ $\mathrm{V}(\mathrm{IV})$ extraction in $\mathrm{CHCl}_{3}$ phase.

\subsection{Loading of Cyanex 301 with V(IV)}

The cumulative $[\mathrm{V}(\mathrm{IV})]_{(\mathrm{o})}(\mathrm{g} / \mathrm{L})$ has been plotted against the number of phase contact in Figure 6. It is observed that the loading of V(IV) in the organic phase is ended up at the $13^{\text {th }}$ contact. An aliquot of $1 \mathrm{~L} 0.20 \mathrm{~mol} / \mathrm{L} \mathrm{HA}$ is saturated with $5.07 \mathrm{~g} \mathrm{~V}$ (IV) and so the loading capacity is calculated as $7.87 \mathrm{~g} \mathrm{~V}$ (IV) per $100 \mathrm{~g}$ HA. The loading capacity is considerably high, and so it can be recommended for a large scale separation of $\mathrm{V}(\mathrm{IV})$ from an aqueous solution. The extraction of $5.07 \mathrm{~g} \mathrm{~V}(\mathrm{IV}) / \mathrm{L}$ by 1 L 0.20 molar $\mathrm{HA}$ at saturated loading implies the $\mathrm{HA} / \mathrm{V}(\mathrm{IV})$ mole ratio of 2.01 which is identical to that obtained from the extractant dependence study. The loading results indicate that the mechanism of extraction at high loading is not changed from that suggested at low loading.

\subsection{Stripping of V(IV)-Loaded Organic Phase by Mineral Acids}

The maximum V(IV) loaded organic phase containing $5.07 \mathrm{~g} / \mathrm{L} \mathrm{V}(\mathrm{IV})$ with theoretically no free extractant, after proper dilution and adjustment of free [HA], has been subjected for stripping by $0.1,0.3$ and $1.0 \mathrm{~mol} / \mathrm{L} \mathrm{H}_{2} \mathrm{SO}_{4}$, $\mathrm{HNO}_{3}$ and $\mathrm{HCl}$ solutions $303 \mathrm{~K}$ and $\mathrm{O} / \mathrm{A}=1$. The stripping results are given in Table 2 . It is found that stripping percentage is more or less acceptable in all three acids used alone. In all cases, stripping percentage is increased with increasing concentration of acid. It is seen that $71.50 \%$ stripping by $0.10 \mathrm{~mol} / \mathrm{L} \mathrm{H}_{2} \mathrm{SO}_{4}$ is increased to $100 \%$ stripping by $1 \mathrm{~mol} / \mathrm{L} \mathrm{H}_{2} \mathrm{SO}_{4}$. Similarly, $45 \%$ stripping by $0.10 \mathrm{~mol} / \mathrm{L} \mathrm{HCl}$ is increased to $94 \%$ stripping with $1 \mathrm{~mol} / \mathrm{L} \mathrm{HCl}$; whereas, $78 \%$ stripping by 0.10 $\mathrm{mol} / \mathrm{L} \mathrm{HNO}_{3}$ is increased to $\sim 98 \%$ stripping by $1 \mathrm{~mol} / \mathrm{L}$ $\mathrm{HNO}_{3}$. Sulphuric acid $(1 \mathrm{~mol} / \mathrm{L})$ is sufficient to strip off V(IV) quantitatively. Nitric acid and hydrochloric acid 
Table 1. Evaluation of the values of $K_{e x}$ at $303 \mathrm{~K}$.

\begin{tabular}{|c|c|c|c|c|c|c|c|}
\hline Fig. No. & $\mathbf{p H}_{(\mathrm{eq})}$ & [Cyanex 301], mol/L & {$\left[\mathrm{SO}_{4}^{2-}\right], \mathbf{m o l} / \mathbf{L}$} & Intercept, I & $\log K_{\text {ex }}$ & Avg. $\log K_{e x}$ & Stand. dev. \\
\hline \multicolumn{8}{|c|}{ i) At ler of $\mathrm{SO}_{4}^{2-}$} \\
\hline \multirow{2}{*}{2} & \multirow{2}{*}{ variable } & 0.200 & 0.10 & -2.65 & -1.313 & \multirow{6}{*}{-1.419} & \multirow{6}{*}{0.105} \\
\hline & & 0.300 & 0.10 & -2.50 & -1.517 & & \\
\hline \multirow{2}{*}{3} & 1.42 & \multirow{2}{*}{ variable } & 0.10 & 1.65 & -1.253 & & \\
\hline & 1.78 & & 0.10 & 2.22 & -1.403 & & \\
\hline \multirow{2}{*}{4} & \multirow{2}{*}{1.85} & \multirow{2}{*}{0.225} & \multirow{2}{*}{ variable } & $0.90(l c r)$ & -1.504 & & \\
\hline & & & & $1.08(h c r)$ & -1.523 & & \\
\hline \multicolumn{8}{|c|}{ ii) At hcr of $\mathrm{SO}_{4}^{2-}$} \\
\hline 2 & variable & 0.150 & 1.5 & -2.43 & -0.958 & \multirow[b]{2}{*}{-0.940} & \multirow[b]{2}{*}{0.026} \\
\hline 3 & 1.65 & variable & 1.5 & 2.06 & -0.921 & & \\
\hline
\end{tabular}

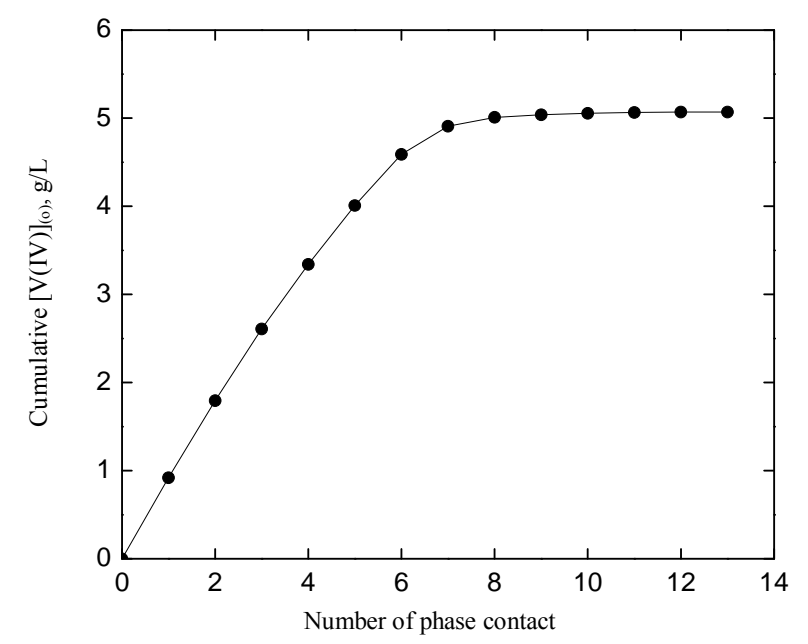

Figure 6. Loading of HA with V(IV). $[\mathrm{V}(\mathrm{IV})]_{(\text {ini) }}=1000 \mathrm{mg} / \mathrm{L}$, $\left[\mathrm{SO}_{4}^{2-}\right]=0.10 \mathrm{~mol} / \mathrm{L}, \mathrm{pH}_{(\mathrm{ini})}=2.60,[\mathrm{HA}]=0.20 \mathrm{~mol} / \mathrm{L}$, Stage equilibration time $=15 \mathrm{~min}$, Temp. $=303 \mathrm{~K}, \mathrm{O} / \mathrm{A}=1(\mathrm{O}=$ $100 \mathrm{~mL}$ ).

can also be used in stripping if two stage stripping is practiced.

It is reported that Cyanex 302 and Cyanex 301 undergo oxidation in oxidizing environment [28-31] (oxidation products being $\mathrm{R}_{2}(\mathrm{P}=\mathrm{S})-\mathrm{S}-\mathrm{S}-(\mathrm{S}=\mathrm{P}) \mathrm{R}_{2}, \mathrm{R}_{2}(\mathrm{P}=\mathrm{S}) \mathrm{OH}$ and $\left.\mathrm{R}_{2}(\mathrm{P}=\mathrm{O}) \mathrm{OH}\right)$. It can be demonstrated, however, that when $\mathrm{V}(\mathrm{IV})$ is extracted repeatedly from fresh aqueous solutions $\left([\mathrm{V}(\mathrm{IV})]=0.20 \mathrm{~g} / \mathrm{L},\left[\mathrm{SO}_{4}^{2-}\right]=0.10 \mathrm{~mol} / \mathrm{L}\right.$, $\mathrm{pH}_{\text {(ini) }}=1.50$ ) by $0.30 \mathrm{~mol} / \mathrm{L} \mathrm{HA}$ in kerosene (fresh in the first step and regenerated afterwards) and stripped subsequently with $1 \mathrm{~mol} / \mathrm{L} \mathrm{H}_{2} \mathrm{SO}_{4}$, then $(79 \pm 2) \%$ extraction and $100 \%$ stripping are observed from the 1 st -25 th extraction-stripping steps. It is therefore concluded that HA does not undergo any sort of oxidation as also reported by Sole et al. [32].
Table 2. Stripping of V(IV) loaded organic phase using different acid solutions. $[\mathrm{V}(\mathrm{IV})]_{(0)}=200 \mathrm{mg} / \mathrm{L}$, [Cyanex 301] $=$ $0.10 \mathrm{~mol} / \mathrm{L}$, Equilibration time $=1 \mathrm{~h}$, Temp. $=(303 \pm 0.5) \mathrm{K}$, $\mathrm{O} / \mathrm{A}=1(\mathrm{O}=\mathbf{2 0} \mathrm{mL})$.

\begin{tabular}{cccc}
\hline $\begin{array}{c}\text { Stripping } \\
\text { agent }\end{array}$ & $\begin{array}{c}\text { Acid concentration, } \\
\text { mol/L }\end{array}$ & $\begin{array}{c}{[\mathbf{V}(\mathbf{I V})]_{(\mathbf{a q})},} \\
\mathbf{m g} / \mathbf{L}\end{array}$ & $\begin{array}{c}\text { \% of V(IV) } \\
\text { stripped }\end{array}$ \\
\hline & 0.10 & 140.0 & 71.5 \\
$\mathrm{H}_{2} \mathrm{SO}_{4}$ & 0.30 & 190.0 & 95.0 \\
& 1.00 & 200.0 & 100.0 \\
& 0.10 & 90.0 & 45.0 \\
$\mathrm{HCl}$ & 0.30 & 170.0 & 85.0 \\
& 1.00 & 180.0 & 94.0 \\
& 0.10 & 156.0 & 78.0 \\
$\mathrm{HNO}_{3}$ & 0.30 & 165.6 & 82.8 \\
& 1.00 & 195.3 & 97.7 \\
\hline
\end{tabular}

\subsection{Separation Ability of V(IV) from Some Other Metal Ions}

In order to examine the effectiveness of HA towards the mutual separations of some 3d-block metal ions viz. Ti(IV), V(IV), Fe(III), Co(II), Ni(II), Cu(II) and Zn(II), the extraction percentages of these metal ions have been estimated. For this purpose, $0.20 \mathrm{~g} / \mathrm{L}$ metal ion is extracted from $0.10 \mathrm{~mol} / \mathrm{L} \mathrm{SO}_{4}^{2-}$ (or, $\left[\mathrm{SO}_{4}^{2-}\right]=\mathrm{H}_{2} \mathrm{SO}_{4}$ when $\left.\left[\mathrm{H}_{2} \mathrm{SO}_{4}\right]>0.10 \mathrm{~mol} / \mathrm{L}\right)$ medium at different $\mathrm{pH}_{(\mathrm{eq})}$ values by $0.10 \mathrm{~mol} / \mathrm{L} \mathrm{HA}$ in kerosene at $303 \mathrm{~K}$ and $\mathrm{O} / \mathrm{A}$ $=1(\mathrm{O}=20 \mathrm{~mL})$ on equilibration for $1 \mathrm{~h}$. The extraction results given in Table 3 predict the following:

1) $\mathrm{V}(\mathrm{IV})$ can be separated from $\mathrm{Cu}(\mathrm{II})$ at $\mathrm{pH} 0$ in single step $(0 \% \mathrm{~V}(\mathrm{IV})$ extraction and $100 \% \mathrm{Cu}(\mathrm{II})$ extraction).

2) On using counter-current extraction stages, V(IV) 
Table 3. Solvent extraction data of some $3 d$-block elements by Cyanex 301 dissolved in kerosene. $[$ Cyanex 301] $=0.10$ $\mathrm{mol} / \mathrm{L}$ (in kerosene); [Metal ion] $=0.20 \mathrm{~g} / \mathrm{L}$; $\left[\mathrm{SO}_{4}^{2-}\right]=$ $\left[\mathrm{H}_{2} \mathrm{SO}_{4}\right]$ or $0.10 \mathrm{~mol} / \mathrm{L}, \mathrm{Temp}=303 \mathrm{~K}, \mathrm{O} / \mathrm{A}=1(\mathrm{O}=20 \mathrm{~mL})$, Equilibration time $=1 \mathrm{~h}$.

\begin{tabular}{cccccccc}
\hline $\mathbf{p H}_{(\mathrm{eq})}$ & $\mathbf{V ( I V )}$ & $\mathbf{T i}(\mathrm{IV})$ & $\mathbf{F e}(\mathrm{III})$ & $\mathbf{C o}(\mathrm{II})$ & $\mathbf{N i}(\mathrm{II})$ & $\mathbf{C u}(\mathrm{II})$ & $\mathbf{Z n}(\mathrm{II})$ \\
\hline 0.0 & $\mathrm{NE}$ & $\mathrm{NE}$ & 11.0 & 8.0 & 8.0 & $\mathrm{CE}$ & 72.0 \\
0.5 & 1.0 & $\mathrm{NE}$ & 82.0 & 30.0 & 35.0 & $\mathrm{CE}$ & 98.0 \\
1.0 & 4.3 & 0.9 & 99.0 & 67.0 & 76.0 & & $\mathrm{CE}$ \\
1.5 & 38.7 & 6.2 & $\mathrm{CE}$ & 91.0 & 95.0 & & $\mathrm{CE}$ \\
2.0 & 86.3 & 35.5 & $\mathrm{CE}$ & 98.0 & 99.0 & & \\
2.5 & 96.2 & 70.6 & & 99.5 & $\mathrm{CE}$ & & \\
3.0 & 98.4 & $90.5^{*}$ & & $\mathrm{CE}$ & $\mathrm{CE}$ & & \\
3.5 & 99.1 & 96.8 & & $\mathrm{CE}$ & & & \\
4.0 & $\mathrm{CE} *$ & 98.9 & & $\mathrm{CE}$ & & & \\
4.5 & & $\mathrm{CE}$ & & & & & \\
\hline
\end{tabular}

NE: non-extractable, CE: complete extraction; ${ }^{*}$ Aqueous solution becomes cloudy before extraction but becomes clear after extraction.

can be separated from:

- $\mathrm{Zn}(\mathrm{II})$ at $\mathrm{pH} \sim 0.5(1 \% \mathrm{~V}(\mathrm{IV})$ extraction and $98 \%$ $\mathrm{Zn}(\mathrm{II})$ extraction),

- $\mathrm{Fe}(\mathrm{III})$ at $\mathrm{pH} 1.0$ (4.3\% V(IV)-extraction and $99 \%$ $\mathrm{Fe}(\mathrm{III})$-extraction),

- $\mathrm{Co}(\mathrm{II})$ at $\mathrm{pH} 1.5$ (38.7\% V(IV)-extraction and 91\% Co(II) extraction), and

- $\mathrm{Ni}(\mathrm{II})$ at $\mathrm{pH} 1.5$ (38.7\% V(IV)-extraction and 95\% $\mathrm{Ni}(\mathrm{II})$ extraction).

3) Separation of V(IV) from Ti(IV) is difficult but not impossible. Separation can be achieved at $\mathrm{pH} 2.0$ on using counter-current multistage extraction.

\section{Conclusions}

The following conclusions are drawn:

1) Vanadium(IV) can be extracted by $\mathrm{HA}$ at $\mathrm{pH}$ above 1. The equilibration time $10 \mathrm{~min}$. Up to at least $0.30 \mathrm{~g} / \mathrm{L}$ $\mathrm{V}(\mathrm{IV})$, the extraction ratio (D) is independent of V(IV) concentration in the aqueous phase.

2) The corrected extraction ratio $\left({ }^{C} \mathrm{D}\right)$ is proportional to $\left[\mathrm{H}^{+}\right]^{-2}$ at its $\mathrm{lcr},[\mathrm{HA}]^{2}$ and the factor $(1+1.58$ $\left.\left[\mathrm{SO}_{4}^{2-}\right]\right)$. The $\mathrm{K}_{\mathrm{ex}}$ values at $303 \mathrm{~K}$ are $10^{-1.419}$ and $10^{-0.94}$ in 0.10 and $1.50 \mathrm{~mol} / \mathrm{L} \quad \mathrm{SO}_{4}^{2-}$ medium, respectively.

3) The extraction process is endothermic with a $\Delta \mathrm{H}$ value of $16 \mathrm{~kJ} / \mathrm{mol}$.

4) The extracted species are $\mathrm{VOA}_{2}$ at $l c r$ and $\mathrm{VO} \cdot \mathrm{HSO}_{4} \cdot \mathrm{A} \cdot \mathrm{HA}$ or $\mathrm{VOSO}_{4}$ at $h c r$ of $\mathrm{SO}_{4}^{2-}$.

5) $100 \mathrm{~g} \mathrm{HA}$ can extract as much as $7.87 \mathrm{~g} \mathrm{~V}(\mathrm{IV})$. This gives $\mathrm{HA} / \mathrm{V}(\mathrm{IV})$ mole ratio of 2.01 indicating that the mechanism of extraction is not changed with loading.
6) Among the diluents used, kerosene is the best. The least effective diluent is $\mathrm{CHCl}_{3}$ followed by $1,2-\mathrm{C}_{2} \mathrm{H}_{4} \mathrm{Cl}_{2}$ and xylene.

7) $1 \mathrm{~mol} / \mathrm{L} \mathrm{H}_{2} \mathrm{SO}_{4}, \mathrm{HCl}$ and $\mathrm{HNO}_{3}$ can strip off $100 \%$, $94 \%$ and $97.7 \% \mathrm{~V}(\mathrm{IV})$, respectively, in single step.

8) Using HA as extractant, V(IV) can be separated from $\mathrm{Cu}$ (II). It can be separated from $\mathrm{Zn}$ (II) at $\mathrm{pH} 0.5$ but for clear-cut separation counter-current 2-3 stage extractions may be required. In a similar way, V(IV) can be separated from $\mathrm{Fe}(\mathrm{III})$ at $\mathrm{pH} 1$.

Separations V(IV) from Ti(IV), Co(II) and Ni(II) by HA appear to be difficult.

\section{REFERENCES}

[1] S. Prakash, G. D. Tuli, S. K. Banu and R. D. Madan, "Advanced Inorganic Chemistry," S. Chand and Company Ltd., New Delhi, 1990.

[2] R. K. Biswas, M. Wakihara and M. Taniguchi, "Recovery of Vanadium and Molybdenum from Heavy Oil Desulphurization Waste Catalyst," Hydrometallurgy, Vol. 14, No. 2, 1985, pp. 219-230. doi:10.1016/0304-386X(85)90034-9

[3] C. O. Gomez-Bueno, D. R. Spink and G. L. Rempel, "Extraction of Vanadium from Athabasca Tar Sands Fly Ash," Metallurgical and Materials Transactions B, Vol. 12, No. 2, 1981, pp. 341-352.

[4] T. Sekine and Y. Hasegawa, "Solvent Extraction Chemistry: Fundamentals and Applications," Marcel Dekker, Inc., New York, 1977, pp. 564-567.

[5] F. Islam and R. K. Biswas, "The Solvent Extraction of Vanadium(IV) with HDEHP in Benzene and Kerosene: The Solvent Extraction of Vanadium(IV) from Sulphuric Acid Solution with Bis-(2-Ehylhexyl) Phosphoric Acid in Benzene and Kerosene," Journal of Inorganic and $\mathrm{Nu}$ clear Chemistry, Vol. 42, 1980, pp. 415-420. doi:10.1016/0022-1902(80)80018-2

[6] F. Islam and R. K. Biswas, "Kinetics of Solvent Extraction of Metal Ions with HDEHP-II: Kinetics and Mechanism of Solvent Extraction of V(IV) from Acidic Aqueous Solutions with Bis-(2-Ethylhexyl)Phosphoric Acid in Benzene" Journal of Inorganic and Nuclear Chemistry, Vol. 42, No. 3, 1980, pp. 421-429. doi:10.1016/0022-1902(80)80019-4

[7] T. Sato, T. Nakamura and M. Kawamura, "The Extraction of Vanadium(IV) from Hydrochloric Acid Solutions by Di-(2-Ethylhexyl)-Phosphoric Acid," Journal of Inorganic and Nuclear Chemistry, Vol. 40, No. 5, 1978, pp. 853-856. doi:10.1016/0022-1902(78)80164-X

[8] J. P. Brunette, F. Rastegar and M. J. F. Leroy, "Solvent Extraction of Vanadium(V) by Di-(2-Ethylhexyl)-Phosphoric Acid from Nitric Acid Solutions," Journal of Inorganic and Nuclear Chemistry, Vol. 41, No. 5, 1979, pp. 735-737. doi:10.1016/0022-1902(79)80364-4

[9] M. A. Hughes and R. K. Biswas, "The Kinetics of Vanadium(IV) Extraction in the Acidic Sulphate-D2EHPAn-Heptane System Using the Rotating Diffusion Cell 
Technique," Hydrometallurgy, Vol. 26, No. 3, 1991, pp. 281-297. doi:10.1016/0304-386X(91)90005-7

[10] R. S. Juang and R. H. Lo, "Stoichiometry of Vanadium(IV) Extraction from Sulfate Solutions with Di(2Ethylhexyl) Phosphoric Acid Dissolved in Kerosene," Journal of Chemical Engineering of Japan, Vol. 26, No. 2, 1993, pp. 219-222. doi:10.1252/jcej.26.219

[11] R. K. Biswas and M. G. K. Mondal, "Kinetics of $\mathrm{VO}^{2+}$ Extraction by D2EHPA," Hydrometallurgy, Vol. 69, No. 1-3, 2003, pp. 117-133. doi:10.1016/S0304-386X(02)00208-6

[12] J. Saji and M. L. P. Reddy, "Solvent Extraction Separation of Vanadium(V) from Multivalent Metal Chloride Solution Using 2-Ethylhexyl Phosphonic Acid Mono-2Ethylhexyl Ester," Journal of Chemical Technology and Biotechnology, Vol. 77, No. 10, 2002, pp. 1149-1156. doi:10.1002/jctb.690

[13] J. Saji and M. L. P. Reddy, "Selective Extraction and Separation of Titanium(IV) from Multivalent Metal Chloride Solutions Using 2-Ethylhexyl Phosphonic Acid Mono 2-Ethylhexyl Ester," Separation Science and Technology, Vol. 38, No. 2, 2003, pp. 427-441. doi:10.1081/SS-120016583

[14] J. Saji, J. K. Saji and M. L. P. Reddy, "Liquid-Liquid Extraction of Tetravalent Titanium from Acidic Chloride Solutions by Bis(2,4,4-Trimethylpentyl)Phosphinic Acid," Solvent Extraction and Ion Exchange, Vol. 18, No. 5, 2000, pp. 877-894. doi:10.1080/07366290008934712

[15] M. Ulewicz and W. Walkowiak, "Selective Removal of Transition Metal Ions in Transport through Polymer Inclusion Memberances with Organophosphorus Acid," Environment Protection Engineering, Vol. 31, No. 3-4, 2005, pp. 74-81.

[16] W. A. Rickelton, "Novel Uses for Thiophosphinic Acids in Solvent Extraction," Journal of Metals, Vol. 44, No. 5, 1992, pp. 52-54.

[17] A. Saily and S. N. Tandon, "Liquid-Liquid Extraction Behavior of V(IV) Using Phosphinic Acids as Extractants," Fresenius' Journal of Analytical Chemistry, Vol. 360, No. 2, 1998, pp. 266-270. doi: $10.1007 / \mathrm{s} 002160050688$

[18] P. Zhang, K. Inoue and H. Tsuyama, "Recovery of Molybdenum and Vanadium from Spent Hydrodesulfurization Catalysts by Means of Liquid-Liquid Extraction," Kagaku KogakuRonbunshu, Vol. 21, No. 1, 1995, pp. 451456. doi:10.1252/kakoronbunshu.21.451

[19] P. Zhang, K. Inoue, K. Yoshizuka and H. Tsuyama, "Solvent Extraction of Vanadium(IV) from Sulfuric Acid Solution by Bis(2,4,4-Trimethylpentyl)Phosphinic Acid in Exxsol D80," Journal of Chemical Engineering of Japan, Vol. 29, No. 1, 1996, pp. 82-87. doi:10.1252/jcej.29.82

[20] R. K. Biswas and A. K. Karmakar, "Equilibrium of the Extraction of V(IV) in the V(IV)- $\mathrm{SO}_{4}{ }^{2-}\left(\mathrm{H}^{+}, \mathrm{Na}^{+}\right)-$Cyanex 302-Kerosene System," International Journal of Nonfer- rous Metallurgy, Vol. 1, 2012, pp. 23-31.

[21] K. C. Sole and J. B. Hiskey, "Solvent Extraction Characteristics of Thio Substituted Organophosphinic Acid Extractants," Hydrometallurgy, Vol. 30, 1992, pp. 345-365. doi:10.1016/0304-386X(92)90093-F

[22] J. Bassett, R. C. Denney, G. H. Jeffery and J. Mendham, "Vogel's Textbook of Quantitative Inorganic Analysis including Elementary Instrumental Analysis," 4th Edition, ELBS and Longman, London, 1979, pp. 752-753.

[23] M. R. Ali, R. K. Biswas, S. M. A. Salam, A. Akhter, A. K. Karmakar and M. H. Ullah, "Cyanex 302: An Extractant for $\mathrm{Fe}^{3+}$ from Chloride Medium," Bangladesh Journal of Scientific and Industrial Research, Vol. 46, No. 4, 2011, pp. 407-414.

[24] R. K. Biswas and D. A. Begum, "Solvent Extraction of $\mathrm{Fe}(\mathrm{III})$ from Chloride Solution by D2EHPA in Kerosene," Hydrometallurgy, Vol. 50, No. 2, 1998, pp. 153168. doi:10.1016/S0304-386X(98)00048-6

[25] E. Paatero, T. Lantto and P. Ernola, "The Effect of Trioctylphosphine Oxide on Phase and Extraction Equilibria in Systems Containing Bis(2,4,4-Trimethylpentyl) Phosphinic Acid," Solvent Extraction and Ion Exchange, Vol. 8, No. 3, 1990, pp. 371-388. doi:10.1080/07366299008918006

[26] E. C. Potterr, "Electrochemical Principles and Applications," Cleaver House Press, London, 1961, p. 51.

[27] R. M. Smith and A. E. Martell, "Critical Stability Constants," Inorganic Complexes, Vol. 4, Plenum Press, New York and London, 1976.

[28] N. E. El-Hefny, "Kinetics and Mechanism of Extraction of $\mathrm{Cu}$ (II) by Cyanex 302 from Nitrate Medium and Oxidative Stripping of $\mathrm{Cu}(\mathrm{I})$ using Lewis Cell," Chemical Engineering and Processing, Vol. 49, No. 12, 2010, pp. 84-90. doi:10.1016/j.cep.2009.11.012

[29] K. C. Sole and J. B. Hiskey, "Solvent Extraction of Copper by Cyanex 272, Cyanex 302 and Cyanex 301," Hydrometallurgy, Vol. 37, No. 2, 1995, pp. 129-147. doi:10.1016/0304-386X(94)00023-V

[30] A. Bhattacharyya, P. K. Mohapatra and V. K. Manchanda, "Seperation of Americium(III) and Europium(III) from Nitrate Medium Using a Binary Mixture of Cyanex 301 with N-Donor Ligands," Solvent Extraction and Ion Exchange, Vol. 24, 2006, pp. 1-17. doi:10.1080/07366290500388459

[31] B. Menoya, M. P. Elizalde and A. Almela, "Determination of the Degradation Compounds Formed by the Oxidation of Thiophosphinic Acids and Phosphine Sulphides with Nitric Acid," Analytical Sciences, Vol. 18, 2002, pp. 799-804. doi:10.2116/analsci.18.799

[32] K. C. Sole, J. B. Hiskey and T. L. Ferguson, "An Assessment of the Long Term Stabilities of Cyanex 302 and Cyanex 301 in Sulfuric and Nitric Acids," Solvent Extraction and Ion Exchange, Vol. 11, 1993, pp. 783-796. doi: $10.1080 / 07366299308918186$ 


\section{Notations and Abbreviations}

\begin{tabular}{|c|c|}
\hline$\Delta \mathrm{H}$ & Apparent enthalpy change \\
\hline$\varepsilon$ & Dielectric constant \\
\hline${ }^{\mathrm{C}} \mathrm{D}$ & $\mathrm{D}$ at a constant $\mathrm{pH}_{(\mathrm{eq})}$ and $[\mathrm{HA}]_{(\mathrm{o}, \mathrm{eq})}$ \\
\hline $\mathrm{D}$ & Extraction or distribution ratio \\
\hline HA & Cyanex 301 (monomeric) \\
\hline$h c r$ & Higher concentration region \\
\hline$h p H r$ & Higher $\mathrm{pH}$ region \\
\hline $\mathrm{K}_{\mathrm{ex}}$ & Extraction equilibrium constant \\
\hline $\mathrm{K}_{\mathrm{SO}_{4}}$ & A proportionality constant in sulphate dependence study \\
\hline $\mathrm{L}$ & Co-existing anion except $\mathrm{OH}^{-}$in the aqueous phase \\
\hline lcr & Lower concentration region \\
\hline $\mathrm{lpHr}$ & Lower $\mathrm{pH}$ region \\
\hline $\mathrm{R}$ & $\mathrm{CH}_{3}-\mathrm{C}\left(\mathrm{CH}_{3}\right)_{2}-\mathrm{CH}_{2}-\mathrm{CH}\left(\mathrm{CH}_{3}\right)-\mathrm{CH}_{2}-$ \\
\hline[] & Sign of complex species \\
\hline[] & Sign of concentration \\
\hline Suffix (o) & Organic phase \\
\hline (ini) & Initial \\
\hline (eq) & Equilibrium \\
\hline (aq) & Aqueous phase \\
\hline
\end{tabular}

